\title{
„Całożyciowe uczenie się” pedagogów-artystów na tle ich autobiografii zawodowych
}

\begin{abstract}
Streszczenie: Artykuł nawiązuje do fragmentu badań autobiograficznych dotyczących specyfiki rozwoju zawodowego pedagogów-nauczycieli plastyki, którzy łączą pracę pedagogiczną z własną twórczością artystyczną. W pierwszej części zaprezentowane są niektóre elementy procedury badawczej: przedmiot badań, charakterystyka terenu badań i próby badawczej, a także analiza zastosowanej metody autobiograficznej oraz techniki wywiadu narracyjnego. Znaczna część wystąpienia poświęcona jest prezentacji wyników badań dotyczących całożyciowego uczenia się pedagogów-artystów. Na zakończenie przedstawione są konkluzje wynikające $\mathrm{z}$ badań.

Słowa kluczowe: edukacja artystyczna, pedagog, nauczyciel plastyki, artysta, rozwój zawodowy, autobiografia.
\end{abstract}

\section{The lifelong learning of educators-artists On background their professional autobiographies}

Summary: The article refers to aspects of autobiographical research relating to the specific of the professional development of educators - fine art teachers' who combine their own artistic work with their pedagogical work. In the first part of article various elements of the research are presented including the object of analysis, characterisation of the environment of investigations and an investigative test. A characteristic analysis, as applied in the autobiographical method, was carried out as well as the technique of a narrative interview. Furthermore, an evaluation of the autobiographical material is also presented. A large part of the article is devoted to the presentation of the research results relating to the specific of the teacher's professional development. The last part of the article includes the research conclusions.

Keywords: the art education at school, the educator, teacher of fine arts, the artist, the professional development, autobiography.

* Uniwersytet w Białymstoku, Wydział Pedagogiki i Psychologii, Zakład Pedagogiki Ogólnej i Metodologii Badań Pedagogicznych, 15-328 Białystok, ul. Świerkowa 20; b.kunat@uwb.edu.pl 


\section{Wprowadzenie}

Na jakość życia człowieka, na rozwijanie jego potrzeb intelektualnych i estetycznych znaczący wpływ ma właściwie przeprowadzona na etapie szkolnym edukacja plastyczna. Raport Arts and Cultural Education At School In Europe wskazuje na jej niski status oraz zjawisko deprecjonowania przedmiotów artystycznych $(2009 \text {, s. } 76-79)^{1}$. Badania także dowodzą, że w procesie edukacji plastycznej dzieci i młodzieży ważną rolę odgrywa kompetentny nauczyciel plastyki - profesjonalista, który ze względu na przemiany społeczno-kulturowe, zmiany zachodzące w sztuce stoi przed koniecznością ciągłego rozwoju zawodowego (Popek, 1998, s. 41). W związku z brakiem zwartych opracowań teoretycznych oraz badań empirycznych dotyczących rozwoju zawodowego nauczycieli plastyki dostrzegłam potrzebę podjęcia analiz w obrębie tej problematyki. Założyłam, że szersza debata i refleksja nad tą profesją może być skuteczną drogą prowadzącą do zwiększenia jakości i rangi szkolnej edukacji plastycznej.

\section{Teoretyczno-metodologiczne podstawy badań własnych}

Przedmiotem badań uczyniłam rozwój zawodowy nauczycieli plastyki. Przyjęłam holistyczne ujęcie procesu rozwoju zawodowego nauczycieli jako ich „całożyciowego uczenia się" autorstwa Christophera Daya (2004, 2008). Rozwój zawodowy nauczycieli plastyki traktuję całościowo jako dynamiczny i wieloetapowy proces, stanowiący transformację ich doświadczeń związanych z całożyciowym uczeniem się oraz ustawicznym „stawaniem się" usytuowanym w szerokim kontekście społecznym. Jako podstawę teoretyczną przyjęłam również koncepcję pedeutologiczną pedagoga-artysty/twórcy opracowaną przez Stefana Szumana, zgodnie z którą nauczyciel z zakresu edukacji artystycznej powinien mieć profesjonalne przygotowanie zarówno artystyczne, jak i pedagogiczne oraz sam być artystą twórcą (Szuman, za: Tytko, 2009, s. 308). Z tej koncepcji wynika, że o wysokiej randze przedmiotu plastyka decyduje w sposób znaczący nauczyciel plastyki-twórca/artysta, autentyczny, otwarty, bezpośredni w stosunku do młodzieży, animator i przewodnik po wielowymiarowych drogach sztuki, motywujący dzieci i młodzież do podejmowania twórczych działań plastycznych. Nauczyciele plastyki, którzy łączą pracę pedagogiczną z własną twórczością artystyczną, poprzez osobistą pasję i przykład, kreatywną postawę i zaangażowanie, wspierają aktywność plastyczną uczniów, a także stymulują ich rozwój osobowy i artystyczny. Kierując się tymi przesłankami, w swoich badaniach skoncentrowałam się na indywidualnych drogach zawodowych nauczycieli plastyki - pedagogów, a zarazem artystów.

${ }^{1}$ Badania porównawcze dotyczące szkolnej edukacji artystycznej i kulturalnej 30 krajów odnoszące się do roku szkolnego 2007-2008. 
Uznałam, że dla rozpoznania procesu rozwoju zawodowego rozumianego jako całożyciowe uczenie się istotne jest zaprezentowanie tego zjawiska z perspektywy badanych. W związku z tym poznałam autobiografie pedagogów-artystów, których dobrałam w sposób celowy spośród wszystkich nauczycieli plastyki miasta Białegostoku i powiatu białostockiego. Byli to liderzy wyróżniający się na tle grupy specjalistycznym przygotowaniem plastyczno-pedagogicznym, wieloletnim doświadczeniem w pracy na stanowisku nauczyciela plastyki oraz uprawiający twórczość plastyczną. Do badań dobrałam ich, współpracując z instytucjami kulturalno-oświatowymi miasta Białegostoku i powiatu. Celowy dobór próby badawczej wzbogaciłam doborem na zasadzie kuli śnieżnej, polegającym na wzajemnym typowaniu się badanych (Babbie, 2007, s. 205-206). W ten sposób do badań zakwalifikowałam 14 pedagogów-artystów. Poznałam ich subiektywne przeżycia, odczucia i doświadczenia, dotyczące procesu ich rozwoju zawodowego rozumianego jako całożyciowe uczenie się.

W badaniach przyjęłam biograficzną perspektywę metodologiczną (Urbaniak-Zając, 2011) wynikającą z humanistycznego paradygmatu nauk społecznych (Dróżka, 1997, s. 23-24), gdyż interesowało mnie uchwycenie procesu rozwoju zawodowego pedagogów-artystów poprzez odwoływanie się do subiektywnej perspektywy indywidualnego podmiotu, do jego interpretacji. Zdecydowałam się na prowadzenie badań biograficznych, gdyż dzięki nim można poznać specyfikę określonych grup społecznych (Urbaniak-Zając, 2005, s. 119), szczególne zaś jednostek, których historie życia są na tyle znaczące, że można poprzez nie dowiedzieć się czegoś ważnego o człowieku i o świecie. Sytuując swoje przedsięwzięcie badawcze w nurcie biograficznym, miałam świadomość funkcjonowania jego różnych strategii i podejść teoretyczno-metodologicznych. Uznałam, że charakter celów i problematyki uzasadnia zastosowanie metody autobiograficznej stanowiącej pewną część metody biograficznej (Dróżka, 2009, s. 60). Autobiografię, zgodnie z ujęciem Danuty Lalak, rozumiem jako biografię podmiotową, w której badany jest równocześnie podmiotem opisywanych wydarzeń (Lalak, 2010, s. 106)². Mając na uwadze to, że przebieg życia człowieka można poznawać kompleksowo lub poprzez jego fragmenty strukturalizowane w oparciu o różne kryteria, uzyskałam typ relacji autobiograficznych określanych przez Normana Denzina jako biografia tematyczna (Denzin, 1990, s. 67). Zakres tematyczny autobiografii ograniczyłam do życia zawodowego. Szukając odpowiedniej techniki badawczej, wyszłam z założenia, że podejście jakościowe do autobiografii wymaga badania ludzkiego doświadczenia w jego naturalnym otoczeniu i kontekście biograficznym oraz bezpośredniego dostępu do rzeczywistości społecznej (Dróżka, 2009, s.60).OdwołującsiędokoncepcjiFritzaSchütze,jakotechnikęgromadzeniamateriału empirycznegozastosowałamwywiadnarracyjny(Schütze,za:Urbaniak-Zając, 1999,

${ }^{2}$ Danuta Lalak w klasyfikacji biografii rozumianej jako opis życia wyróżnia biografię podmiotową jako opis własnego życia (autobiografia) obok biografii przedmiotowej (opis cudzego życia - biografia) (Lalak, 2010, s. 106). 
s. 29)3 . Założyłam, że poprzez wywiad narracyjny uda się zrekonstruować doświadczenia życia zawodowego pedagogów-artystów, gdyż on w szczególny sposób nadaje się do ujawnienia procesualności zjawisk społecznych (Jakob, 2001, s. 112). Narzędziem, które wykorzystałam, prowadząc wywiad narracyjny, był jego scenariusz zawierający pytanie główne, inicjujące swobodną narrację, oraz pytania uzupełniające.

Badania autobiograficzne realizowałam w trzech fazach: przygotowawczej, badań wstępnych i właściwych. W przygotowywaniu się do prowadzenia wywiadów narracyjnych kierowałam się zaproponowanymi przez Petera Alheita zasadami: dokładnego przygotowania się do wywiadu; przeprowadzania wywiadu z ludźmi, którzy naprawdę interesują badacza ze względu na osobę lub specyficzny problem badawczy; otwartego celu wywiadu; niespieszenia się i okazywania zainteresowania; nieingerowania $\mathrm{w}$ opowieść; unikania w początkowej fazie wywiadu pytań „dlaczego?, po co?”; pozostawienia szczegółowych pytań na koniec wywiadu (Alheit, 2002, s. 103-111). Badania właściwe realizowałam w latach 2010/2011. Korzystając z opracowanych przez F. Schütze etapów wywiadu narracyjnego: fazy otwartego opowiadania, fazy pytań uzupełniających i fazy bilansowania (Schütze, za: Krüger, 2001, s. 85), wyłoniłam pięć faz prowadzenia narracji: wprowadzenie do wywiadu; stymulacji do opowiadania narracji; otwartego opowiadania; pytań uzupełniających i bilansujących oraz zakończenia wywiadu.

Po uzyskaniu materiału autobiograficznego, dzięki wywiadom narracyjnym dokonałam jakościowej analizy danych w kilku etapach: transkrypcji wywiadów; właściwej analizy danych (grupowanie i porządkowanie zebranych materiałów); opisu i prezentacji badanego zjawiska.

\section{Analiza wyników badań własnych}

Rekonstrukcja przebiegu życia zawodowego pedagogów-artystów wskazała na specyficzne wydarzenia i sytuacje znaczące w procesie ich całożyciowego uczenia się. Analiza wertykalna autobiografii pozwoliła na uchwycenie indywidualnych dróg ich życia zawodowego, a w konsekwencji na pokazanie procesu ich rozwoju zawodowego jako transformacji doświadczeń, wydarzeń, zjawisk, powiązanych z życiem osobistym i rodzinnym oraz szerszym kontekstem społeczno-kulturowym i polityczno-ekonomicznym. Analiza porównaw-

${ }^{3} \mathrm{~W}$ literaturze metodologicznej wywiad narracyjny jest traktowany jako technika badawcza (wyłącznie jako sposób gromadzenia danych) lub metoda (koncepcja) badawcza (procedura badań narracyjnych), której przysługuje odpowiedni sposób gromadzenia i analizy materiału: formalna analiza tekstu, opis strukturalny, analityczna abstrakcja, analiza wiedzy, kontrastowe porównywanie, budowanie modelu teoretycznego (Urbaniak-Zając, 1999, s. 29; Jakob, 2001, s. 112). 
cza (horyzontalna) autobiografii badanych dowiodła, że proces ich uczenia się zawodowego związany jest $\mathrm{z}$ różnymi ich doświadczeniami i zdarzeniami zachodzącymi na przestrzeni czasu. W rozwoju zawodowym pedagogów-artystów można wyróżnić kilka następujących po sobie etapów związanych z permanentnym uczeniem się: kształcenie wstępne i przygotowanie zawodowe; rozpoczynanie kariery zawodowej; dochodzenie do autonomii i profesjonalizmu zawodowego. W obrębie etapów rozwoju zawodowego można zidentyfikować potrzebę pedagogów-artystów nieustannego uczenia się od innych oraz uczenia się z innymi.

\section{„Uczenie się od innych”, „uczenie się z innymi” na etapie kształcenia wstępnego}

$\mathrm{Z}$ analizy materiału autobiograficznego wynika, że kształcenie wstępne było dla pedagogów-artystów etapem intensywnej pracy nad sobą. Uwidaczniają się dwa wyraźne trendy interpretowania przez badanych znaczenia etapu kształcenia wstępnego i przygotowania zawodowego $\mathrm{w}$ procesie ich rozwoju zawodowego. Po pierwsze - traktowanie okresu studiów jako czasu formalnego przygotowania do zawodu i po drugie - jako procesu podmiotowego stawania się człowiekiem, czasu dojrzewania osobowego oraz kształtowania się tożsamości zawodowej. Studia były okresem uświadomienia sobie, że praca pedagogiczna wymaga ustawicznego uczenia się. Zdaniem badanych był to czas dowartościowywania się; rodzenia się poczucia własnej wyjątkowości oraz „rozwijania skrzydeł” na wielu płaszczyznach. Kształcenie wstępne związane było z permanentnym uczeniem się poprzez podmiotową wymianę doświadczeń, której sprzyjał klimat uczelni artystyczno-pedagogicznych. Partnerskie interakcje z wykładowcami wpływały na kształtowanie się pozytywnego wizerunku relacji uczeń - nauczyciel. Kontakty z rówieśnikami oparte na wzajemnej współpracy budowały atmosferę przyjaźni i szacunku. Etap kształcenia wstępnego przyczyniał się do kreowania postawy twórczej badanych wobec świata oraz otwierania się na życie artystyczno-kulturalne. Specyficzną cechą etapu kształcenia wstępnego nauczycieli plastyki jest to, że jego jakość zależy od modelu przygotowania zawodowego realizowanego w różnych instytucjach kształcących nauczycieli. Kształcenie wstępne na kierunku wychowanie plastyczne, w odczuciach badanych, przygotowywało ich do bycia nauczycielami plastyki - kompetentnymi specjalistami. Absolwenci szkół wyższych artystycznych w swoich przyszłych planach zawodowych często nie uwzględniali profesji nauczycielskiej, więc nie przywiązywali wagi do zdobywania przygotowania pedagogiczno-psychologicznego. Zwracali oni uwagę na specyficzny problem rozdźwięku pomiędzy przygotowaniem teoretycznym a praktyką. Pedagodzy doceniają kształcenie wstępne uzyskane podczas dwuletnich studiów nauczycielskich. Twierdzą, że zdobyli wówczas solidne przygotowanie metodyczne. Uzyskiwanie kwalifikacji do nauczania plastyki na studiach podyplomowych z zakresu sztuki spotykało się z dezaprobatą badanych. 


\section{Uczenie się w pierwszych latach pracy zawodowej}

Etap rozpoczynania kariery zawodowej związany jest z rodzeniem się identyfikacji zawodowej, odkrywaniem możliwości realizowania się w zawodzie nauczyciela. Z materiału narracyjnego wynika, że często jest on potwierdzeniem, że chcą oni wykonywać profesję nauczycielską z powołania, gdyż zawód nauczyciela (pomimo wcześniejszej ich niechęci do niego) stawał się pasją i misją. Swoiste doświadczenia, wydarzenia, sytuacje i odczucia nauczycieli plastyki świadczą o tym, że etap rozpoczynania kariery zawodowej odegrał ogromną rolę w procesie ich adaptacji zawodowej. Fakt rozpoczynania pracy w szkole w charakterze pedagoga-artysty-plastyka sprawiał, że nigdy nie czuli się oni nauczycielami początkującym. Dlatego możemy mówić o ich szybkiej adaptacji zawodowej (Tabor, 2008, s. 103). Do czynników sprzyjających adaptacji młodych, początkujących nauczycieli należy ich wysokie poczucie wartości, indywidualizm i autonomia oraz doświadczenia twórcze na płaszczyźnie artystycznej. Na etapie rozpoczynania kariery zawodowej przez badanych ważnym zjawiskiem było zdobywanie autorytetu w środowisku pracy. Pierwsze sukcesy ich uczniów (np. w wojewódzkich, ogólnopolskich i międzynarodowych konkursach plastycznych) służyły kreowaniu się w środowisku pozytywnego ich wizerunku jako nauczycieli plastyki. Fakt bycia artystą i własne osiągnięcia twórcze były dobrym źródłem ich wysokiej oceny i szacunku w środowisku szkolnym. Materiał narracyjny ujawnia tendencję związku pomiędzy przebiegiem pierwszych lat pracy zawodowej nauczycieli plastyki a poziomem i jakością ich kształcenia wstępnego. Zauważają oni rozdźwięk między teorią i praktyką. Po ukończeniu wyższych uczelni artystyczno-pedagogicznych narratorzy odczuwali braki przygotowania teoretycznego, szczególne w zakresie rozwiązywania problemów wychowawczych. Często wyobrażenia i oczekiwania nauczycieli na temat pracy zawodowej, ukształtowane podczas studiów, były niezgodne z tym, czego doświadczyli podczas pierwszego kontaktu z praktyką. W związku z tym można mówić o odczuwaniu przez badanych szoku zawodowego (Dróżka, 2000). Efektem opisanego zjawiska $\mathrm{w}$ przypadku tych nauczycieli było wypracowanie własnej strategii twórczego działania poprzez intensywne zdobywanie różnorodnych doświadczeń oraz zaangażowanie w realizację nowatorskich pomysłów (projekty, wystawy, konkursy, nowe metody pracy). Rozpoczynanie kariery zawodowej przez nauczycieli plastyki to okres zdobywania nowych doświadczeń oraz ich zaangażowania. Analizując doświadczenia pedagogów-artystów w kontekście ujęcia rozwoju zawodowego Henryki Kwiatkowskiej, zauważa się, że „wrastanie” nauczycieli w role zawodowe świadczy o ich twórczej adaptacji (Kwiatkowska, 1993, s. 73). Odwołujacc się natomiast do teorii rozwoju zawodowego M. Hubermana, można stwierdzić, że badani w pierwszych latach pracy byli bardziej nastawieni na „odkrywanie” i eksperymentowanie niż „przetrwanie” (Huberman, 1995). Wynikało to $\mathrm{z}$ tego, że równocześnie rozpoczynali pracę w zawodzie nauczyciela i realizowali się na płaszczyźnie artystycznej. Wysokie poczucie własnej wartości jako nauczycieli i artystów mobilizowało ich do autonomicznych, nowatorskich poszukiwań. 
Specyficzne zjawisko pojawiające się w pierwszych latach pracy nauczycieli plastyki to adaptacja i identyfikacja zawodowa, która uzależniona była głównie od ich cech osobowości. Czynnikami ułatwiającymi adaptację zawodową badanych przeze mnie nauczycieli były ich predyspozycje, zainteresowania, zdolności. Duże znaczenie $\mathrm{w}$ stawaniu się nauczycielami plastyki w pierwszych latach pracy mają sukcesy zawodowe. $\mathrm{Z}$ analizy wypowiedzi narratorów wynika, że ich sukcesy są dostrzegane na zewnątrz (konkursy, pozytywne relacje z uczniami, atmosfera podczas zajęć) oraz mają wymiar odczuć wewnętrznych (samooceny). Satysfakcję zawodową dawały badanym pozytywne zmiany postaw uczniów wobec edukacji plastycznej. Materiał narracyjny wskazuje również na charakterystyczne uwarunkowania rozwoju zawodowego badanych w pierwszych latach pracy. Do czynników stymulujących ten proces należą: własne predyspozycje i zdolności, pierwsze sukcesy zawodowe oraz wsparcie ze strony innych młodych nauczycieli, doradcy metodycznego (specjalisty) czy doradcza funkcja czasopisma Plastyka w Szkole. Charakterystyczne typy trudności w pierwszych latach pracy to: braki wynikające z kształcenia wstępnego (pedagogiczno-psychologicznego); rozdźwięk między teorią i praktyką; niezadowalające warunki organizacyjno-materialne szkoły; brak stabilizacji zawodowej (konieczność realizacji etatu w kilku placówkach); brak wsparcia ze strony dyrekcji i starszego grona pedagogicznego; niski prestiż przedmiotu plastyka w szkole.

\section{Autonomia i profesjonalizm zawodowy jako efekt ustawicznego doskonalenia i samokształcenia}

Analizując wypowiedzi badanych z perspektywy koncepcji dyscyplin organizacji uczącej się Petera Senge'a (Senge, 1998, s. 21-23), można stwierdzić, że etap dochodzenia nauczycieli plastyki do autonomii i profesjonalizmu zawodowego związany jest ze wzrastającym poczuciem ich mistrzostwa osobistego, $\mathrm{z}$ dojrzałym zaangażowaniem, utożsamianiem się z zawodem, internalizacją jego norm i wartości oraz wzmacnianiem ich relacji z uczniami i współpracownikami. Momentem przełomowym w pracy zawodowej nauczycieli było zrodzenie się ich poczucia autonomii zawodowej, gdy zaczęli odpowiedzialnie, samodzielnie i świadomie podejmować decyzje w kwestii własnego rozwoju zawodowego oraz prowadzić autorefleksję nad własną praktyką zawodową. Odwołując się do typów tożsamości zawodowej nauczycieli H. Kwiatkowskiej, można stwierdzić, że działania nauczycieli plastyki świadczą o ich tożsamości osiągniętej (Kwiatkowska, 2005; 2008, s. 233-234). Specyficzne drogi dochodzenia do profesjonalizmu zawodowego badanych to permanentne samokształcenie i intensywne doskonalenie zawodowe w różnych dziedzinach (twórczości własnej, upowszechniania sztuki, nauk psychologicznych i pedagogicznych, historii sztuki, filozofii oraz projektów unijnych); dokonywanie innowacji pedagogicznych (projekty, plenery, warsztaty, 
wystawy, konkursy, festyny). Zaangażowanie nauczycieli plastyki w proces samokształcenia i doskonalenia zawodowego wynikające z ich wewnętrznej potrzeby, świadomości i odpowiedzialności zawodowej oraz ich twórcze poszukiwania związane z przekraczaniem i zastępowaniem przepisu roli tożsamością osobową świadczą o tym, że znaleźli się oni, zgodnie z teorią rozwoju zawodowego Roberta Kwaśnicy, w stadium postkonwencjonalnym (Kwaśnica, 1993, s. 101-103; 2006, s. 306). Nauczyciele posiadają własną koncepcję rozumienia rzeczywistości edukacyjnej. Dokonują krytycznej analizy działań pedagogicznych, są samodzielni w myśleniu oraz otwarci na poszerzanie wiedzy, wypracowanie twórczych strategii działania. Analiza materiału narracyjnego w kontekście koncepcji Schöna wskazuje na to, że praca zawodowa pedagogów-artystów nosi znamiona „refleksyjnej praktyki”" (Schön, za: Dylak 1996; Czerepaniak-Walczak 1997). Dokonują oni bowiem pogłębionej refleksji zarówno w działaniu oraz refleksji nad działaniem pedagogicznym. Badani cechują się otwartością na różne stanowiska oraz odpowiedzialnością w zakresie przewidywania i analizowania konsekwencji własnych działań edukacyjno-artystycznych.

\section{Konkluzje}

Proces całożyciowego uczenia się zawodowego pedagogów-artystów jest sprzężeniem uwarunkowań wewnętrznych/podmiotowych oraz zewnętrznych/ środowiskowych. Analiza materiału empirycznego dowodzi, że to „czynnik ludzki” - osobowość i predyspozycje nauczycieli, uczniowie, inni nauczyciele, rodzina sprzyjają temu procesowi. Utrudnienia w tym względzie tkwią głównie w zewnętrznym, przedmiotowo-strukturalnym szerokim kontekście funkcjonowania zawodowego tych nauczycieli. Do uwarunkowań zewnętrznych, stanowiących barierę procesu ich uczenia się na różnych etapach życia zawodowego, należą m.in.: niski prestiż edukacji plastycznej w świadomości społecznej; zmiany rozporządzeń i przepisów prawa oświatowego, głównie wprowadzenie przedmiotu sztuka i konsekwencje z tym związane; niedostateczne warunki organizacyjne szkoły; dodatkowe zadania i obowiązki głównie związane z realizacją etatu plastyki w kilku placówkach; słaba baza materialna szkoły; brak wykwalifikowanego doradcy metodycznego nauczycieli plastyki.

Pedagodzy-artyści formują wiele potrzeb w zakresie tworzenia optymalnych warunków ich rozwoju zawodowego. Potrzebują głównie stabilizacji zawodowej, zwiększenia prestiżu edukacji plastycznej w szkole, stabilnej polityki oświatowej w tym zakresie oraz wsparcia ze strony różnych podmiotów.

$\mathrm{Na}$ podstawie analizy wyników badań własnych oraz wybranych koncepcji teoretycznych ${ }^{4}$ opracowałam projekt wspierania całożyciowego procesu rozwo-

${ }^{4}$ Teoretyczne podstawy projektu: Koncepcja wsparcia jako spirali życzliwości S. Kawuli; Koncepcja rozwoju profesjonalnego J. Butler; Koncepcja rozwoju profesjonalnego SMART 
ju zawodowego nauczycieli plastyki (zbieżny z formułowanymi przez nich potrzebami i oczekiwaniami w tym zakresie). Obejmuje on szczegółowy model sieci wspierania rozwoju zawodowego nauczycieli plastyki zawierający: źródła wspierania rozwoju zawodowego nauczycieli; obszary ich wspierania (działania dowartościowujące, regulowanie sfery emocjonalnej, czynności instrumentalno-praktyczne o charakterze strukturalno-materialnym, inicjatywy komunikacyjno-informacyjne) oraz zakładane efekty działań podejmowanych na rzecz wspierania rozwoju zawodowego nauczycieli plastyki. Podstawowym celem projektu jest tworzenie optymalnych warunków do harmonijnego rozwoju zawodowego pedagogów-artystów stosownie do ich potrzeb w tym zakresie; rozbudowywanie sprzężonej wewnątrzszkolnej i zewnętrznej sieci ich wsparcia, promowanie kultury współpracy i partnerstwa opartej na spontanicznych, dobrowolnych relacjach w ramach profesjonalnej grupy odniesienia (grona pedagogicznego, dyrekcji), na współpracy z rodzicami uczniów, doradztwem metodycznym, środowiskiem artystycznym, samorządem lokalnym oraz z instytucjami kształcącymi nauczycieli.

Wsparcie rozwoju zawodowego pedagogów-artystów może być zatem rozpatrywane w kontekście idei organizacji uczącej się ukazującej nowe perspektywy teoretyczne i praktyczne procesów uczenia się, doskonalenia i rozwoju wobec nowych wyzwań cywilizacyjnych (Dróżka, 2004, s. 33). Szkoła jako organizacja ucząca się akcentuje takie zjawiska, jak: uczenie się zespołowe oparte na doświadczeniu i autorefleksji; prowadzenie badań samokształceniowych; zaangażowanie; wypracowywanie oryginalnych strategii działania pedagogicznego; partnerstwo; współpraca; otwarta komunikacja; wiązanie rozwoju osobistego nauczycieli z rozwojem szkoły jako organizacji (ibidem, s. 35). Uczące się organizacje zdolne są do samopoznania, rozumienia swoich problemów i doskonalenia się (Potulicka, 2005, s. 273). Podstawowym warunkiem sprzyjającym rozwojowi zawodowemu pedagogów-artystów jest szkoła postrzegana jako miejsce i przestrzeń ich indywidualnego i zespołowego uczenia się (Michalak, 2009, s. 22-33).

\section{Literatura}

Alheit P., 2002, Wywiad narracyjny, „Teraźniejszość - Człowiek - Edukacja”, nr 3. Arts and Cultural Education At School In Europe, 2009, Wydawnictwo Eurydice, Brussels. Babbie E., 2007, Badania spoteczne w praktyce, Wydawnictwo Naukowe PWN, Warszawa. Czerepaniak-Walczak M., 1997, Aspekty i źródła profesjonalnej refleksji nauczyciela, Wydawnictwo Edytor, Toruń.

C. M. Burke i wspótpracowników; Propozycja wspierania rozwoju zawodowego nauczycieli opracowana na podstawie badań Instytutu Spraw Publicznych; Strategia optymalizacji wsparcia spolecznego w rozwoju zawodowym A. Szczęsnej; Teoria wspierania nauczycieli J. Jonesa, M. Jenki, S. Lord; Koncepcja wspomagania nauczycieli w rozwoju zawodowym R. Kwaśnicy; Propozycja wspomagania rozwoju zawodowego nauczycieli $W$. Dróżki; Teoria wielowymiarowego wspierania nauczycieli $w$ rozwoju J. Kuźmy; Koncepcja wspierania rozwoju zawodowego nauczyciela D. Foorda. 
Day Ch., 2004, Rozwój zawodowy nauczyciela. Uczenie się przez całe życie, thum. J. Michalak, Gdańskie Wydawnictwo Psychologiczne, Gdańsk.

Day Ch., 2008, Od teorii do praktyki. Rozwój zawodowy nauczycieli, thum. J. Michalak, Gdańskie Wydawnictwo Psychologiczne, Gdańsk.

Denzin N. K., 1990, Reinterpretacja metody biograficznej $w$ socjologii: znaczenie a metoda $w$ analizie biograficznej, [w:] J. Włodarek, M. Ziółkowska (red.), Metoda biograficzna w socjologii, PWN, Warszawa-Poznań.

Dróżka W., 2004, Kształcenie i rozwój zawodowy nauczyciela w przestrzeni organizacji uczacej się, „Edukacja”, nr 4.

Dróżka W., 1997, Metoda biograficzna z perspektywy rozwoju orientacji humanistyczno-jakościowej w pedagogice, „Edukacja”, nr 4.

Dróżka W., 2000, Problemy startu zawodowego młodych nauczycieli a tryb ich kształcenia i dalszej stymulacji rozwoju, [w:] H. Kwiatkowska, T. Lewowicki, S. Dylak (red.), Wspótczesność a kształcenie nauczycieli, Wydawnictwo Wyższej Szkoły Pedagogicznej im. Jana Kochanowskiego, ZNP, Warszawa.

Dróżka W., 2009, Autobiografia w badaniach jakościowych, „Pedagogika Kultury”, t. 5, Wydawnictwo Uniwersytetu Marii Curie-Skłodowskiej, Lublin.

Dylak S., 1996, Kształcenie nauczycieli do refleksyjnej praktyki. Zarys genezy, istoty i rozwój koncepcji, „Rocznik Pedagogiczny”, nr 16.

Huberman M., 1995, Professional careers and professional development: Some intersections, [w:] T. R. Guskey, M. Huberman (eds), Professional Development in Education: New Paradigms and Practices, Teachers College Press, New York.

Jakob G., 2001, Wywiad narracyjny w badaniach biograficznych, [w:] D. Urbaniak-Zając, J. Piekarski (red.), Jakościowe orientacje w badaniach pedagogicznych, Wydawnictwo Uniwersytetu Łódzkiego, Łódź.

Krüger H.-H., 2001, Koncepcje i metody badań biograficznych $w$ naukach o wychowaniu, [w:] D. Urbaniak-Zając, J. Piekarski (red.), Jakościowe orientacje $w$ badaniach pedagogicznych, Wydawnictwo Uniwersytetu Łódzkiego, Łódź.

Kwaśnica R., 1993, Przygotowanie pojęciowe i próba analizy potrzeb rozwojowych uczestników ksztatcenia, [w:] R. Kwaśnica (red.), Pytanie o nauczyciela, Wydawnictwo Uniwersytetu Wrocławskiego, Wrocław.

Kwaśnica R., 2006, Wprowadzenie do myślenia o nauczycielu, [w:] Z. Kwieciński, B. Śliwerski (red.), Pedagogika, Wydawnictwo Naukowe PWN, Warszawa.

Kwiatkowska H., 1993, Logika rozwoju zawodowego, „Kształcenie Nauczycieli”, nr 1 (2).

Kwiatkowska H., 2005, Tożsamość nauczycieli. Między anomia a autonomia, Gdańskie Wydawnictwo Psychologiczne, Gdańsk.

Kwiatkowska H., 2008, Pedeutologia, Wydawnictwo Akademickie i Profesjonalne, Warszawa.

Lalak D., 2010, Życie jako biografia. Podejście biograficzne w perspektywie pedagogicznej, Wydawnictwo Akademickie „Żak”, Warszawa.

Michalak J. M., 2009, Przestrzenie uczenia się nauczycieli: uczenie się w środowisku pracy, „Edukacja", nr 4.

Popek S., 1998, W poszukiwaniu wyznaczników modelu nauczyciela plastyki, [w:] K. Olbrycht (red.), Kształcenie pedagogów realizujacych wychowanie plastyczne - w świetle aktualnych potrzeb edukacyjnych $i$ uwarunkowań spoleczno-kulturowych, Wydawnictwo Uniwersytetu Śląskiego, Cieszyn.

Potulicka E., 2005, Uczacy się nauczyciel, szkoła, społeczeństwo, [w:] T. Bauman (red.), Uczenie się jako przedsięwzięcie na całe życie, „Impuls”, Kraków.

Senge P. M., 1998, Piąta dyscyplina. Teoria i praktyka organizacji uczacych się, Wydawnictwo ABC, Warszawa. 
Tabor U., 2008, Biograficzne uwarunkowania rozwoju nauczyciela. Analiza jakościowa, Wydawnictwo Uniwersytetu Śląskiego, Katowice.

Tytko M. M., 2009, Artysta a wychowawca w koncepcji Stefana Szumana, [w:] K. Krasoń, B. Mazepa-Domagała, A. Wąsiński (red.), Intersubiektywność sztuki w recepcji i tworzeniu. Diagnoza, edukacja, wsparcie rozwoju, Wydawnictwo Wyższej Szkoły Administracji, Bielsko-Biała-Katowice.

Urbaniak-Zając D., 1999, Wywiad narracyjny na tle innych technik wywiadu, „Edukacja”, nr 4, s. 29

Urbaniak-Zając D., 2005, Pedagogiczna perspektywa w badaniach narracyjno-biograficznych, [w:] L. Koczanowicz, R. Nahirny, R. Włodarczyk (red.), Narracje - (Auto)biografia - Etyka, Wydawnictwo Dolnośląskiej Szkoły Wyższej, Wrocław.

Urbaniak-Zając D., 2011, Biograficzna perspektywa badawcza, [w:] E. Dubas, W. Świtalski (red.), Uczenie się z (własnej) biografii, Wydawnictwo Uniwersytetu Łódzkiego, Łódź. 